\title{
Institutions and the Economic Performance of Central African Countries
}

\author{
Chérif Sidy Kane ${ }^{1}$, Elomo Zogo Thérèse ${ }^{2}$, Idrissa Yaya Diandy ${ }^{1}$ \\ ${ }^{1}$ Cheikh Anta DIOP, University of Dakar, Dakar, Senegal \\ ${ }^{2}$ University of Yaounde II, Yaounde, Cameroon \\ Email: cherifsidy.kane@ucad.edu.sn,zogoastrid@yahoo.fr, idrissa.diandy@ucad.edu.sn
}

How to cite this paper: Kane, C.S., Thérèse, E.Z. and Diandy, I.Y. (2019) Institutions and the Economic Performance of Central African Countries. Theoretical Economics Letters, 9, 33-48. https://doi.org/10.4236/tel.2019.91004

Received: October 10, 2018

Accepted: January 12, 2019

Published: January 15, 2019

Copyright (c) 2019 by author(s) and Scientific Research Publishing Inc. This work is licensed under the Creative Commons Attribution International License (CC BY 4.0).

http://creativecommons.org/licenses/by/4.0/

cc) (i) Open Access

\begin{abstract}
The purpose of this paper is to examine the combined effect of political and economic institutions on the economic performance of the countries of Central Africa. To do this, we use dynamic panel data over the period 1996-2013. Using Principal Component Analysis (PCA) to understand the multidimensionality of institutions through a composite indicator, and applying the estimation technique based on the Generalized Moment Method (GAM) to capture the impact of institutions on economic performance, we arrive at the following result: analyzed individually or in combination, institutions constitute a real obstacle to economic performance in Central Africa.
\end{abstract}

\section{Keywords}

Political and Economic Institutions, Economic Performance, PCA, GMM, Central Africa

\section{Introduction}

Nowadays, the absence of performance, including economic growth, is one of the major challenges in developing economies. In fact, the majority of Central African countries ${ }^{1}$ have low growth rates (IMF [1] $)^{2}$ : Angola (3\%), Chad (1.8\%), Gabon (4\%), Burundi $(-4.1 \%)$, and Equatorial Guinea (-12.2\%). Although substantial efforts are needed, two countries stand out namely Cameroon (5.9\%) and the Democratic Republic of Congo (7.7\%). Given these statistics, The Cen-

\footnotetext{
${ }^{1}$ Angola, Burundi, Cameroon, Central African Republic, Congo-Brazzaville, Democratic Republic of Congo (DRC), Chad, Gabon, Equatorial Guinea, Sao Tome \& Principe.

${ }^{2}$ Angola, Burundi, Cameroon, Central African Republic, Congo-Brazzaville, Democratic Republic of Congo (DRC), Chad, Gabon, Equatorial Guinea, Sao Tome \& Principe.
} 
tral African countries have low and divergent economic performance leading to two questions: why is there a large difference in economic growth rates and what are the factors explaining the economic performance in these countries?

At the theoretical level, two theses have been put forward. The first is based on the idea that the economic performance of a society depends on its ability to set up institutions that promote the effective application of contracts on the markets $\left(\right.$ North $^{3}$ [2] [3]). This assertion already illustrates the contribution of institutional quality in explaining disparities in development between countries. Instead of blaming the climate, geographic or genetic factors of the population for the poor economic performance, it becomes urgent to look for causes and solutions in terms of the institutional organization. The second, by breaking down institutions into political institutions $s^{4}$ and economic institutions $s^{5}$, makes of these a primary determinant of economic performance. They influence property rights, incentive structures and transaction costs [4].

Empirically, it is known that the institutions significantly improve the gross domestic product per capita, regardless of the selected institutional indicator; they have a statistically significant effect on economic performance [5]. Conversely, "an imperfection of institutions" amount to redefine economic growth following the institutional changes [6]. In the same vein, Flachaire et al. [7] argue that income disparities are strongly correlated with economic institutions, yet political institutions appear to be key actors in development in that they act through their effects on economic and political institutions.

However, little empirical work has focused on the interaction of two types of institutions $^{6}$ (political and economic) on the economic performance of African countries south of the Sahara, particularly in Central Africa. Therefore, this reflection aims to revisits the relationship between institutions and economic performance. Specifically, it analyzes the combined or joint effect of economic and political institutions on the economic performance of Central African countries. The scientific contribution of this paper lies in the fact that when an analysis is made on the institutions and their effects on economic performance, attention is focused, on the one hand, on a single dimension of the institutions and on the other hand, on sub-Saharan African or developing countries in general.

This work aims to fill these gaps by highlighting the individual and the combined effects of (economic and political) institutions on the economic performance of countries rich in natural resources, whose development process is slow to be realized. To achieve our objectives, two methodological approaches are mobilized:

\footnotetext{
${ }^{3}$ Douglass North (Nobel Prize in Economics in 1993) is one of the main authors of the neo-institutionalist theory. This theory focuses on the role of organizations as an alternative to the market in view of the existence of transaction costs.

${ }^{4}$ Example: property rights.

${ }^{5}$ Example: democracy.

${ }^{6}$ Par exemple: comment des reformes effectués sur une catégorie spécifiques d'institutions affectent une autre catégorie d'institutions dans le but de converger vers la prospérité économique.
} 
- Firstly, to take into account the multidimensional nature of institutions, a Principal Component Analysis (PCA) is performed to construct composite indicators.

- Then, using the Generalized Method of Moments [8], we analyze the impact of individual and joint effects of institutions on economic performance. This technique solves the problem of endogeneity between institutions and economic performance on the one hand, and the reciprocal influence of economic and political institutions on the other hand. It also makes it possible to solve the bias of simultaneity, inverse causality and omitted variables.

The structure of this paper is based on three sections: the first 1) presents the theoretical framework of the link between the institutions and economic performance, the second 2) shows the methodological approach for evaluating the individual and combined effects of institutions on economic activity and finally the last 3) deals with the results and implications of economic policies.

\section{Theoretical and Empirical Review}

\subsection{Institutional Contributions on Economic Performance}

Institutions and characteristics of their application are formal or informal constraints that structure human interactions [3]. If formal institutions gather both political ${ }^{7}$ and economic ${ }^{8}$ institutions [4], the so-called informal are a set of customs, beliefs, conventions or standards of conduct in society. The economic institutions carry out the economic functions and influence performance through investment in capital and organization of production [9]. They include the establishment and protection of property rights institutions, transactions facilitation institutions of and Cooperation Economic institutions [10].

It is proved that long-term growth is faster in countries with high institutional capacity to contract, good law enforcement and high property rights protection. Such institutions improve the central bureaucracy of the government, and increase the level of democracy and the level of trust [11].

In the same vein, recent studies show that economic institutions determine actors' motivations and constraints and shape economic outcomes [12]. They also affect the distribution of resources and consequently encourage the emergence of economic growth when political institutions allocate political power to groups whose interests are largely in the enforcement of property rights.

As far as political institutions are concerned, through their impact on political and economic institutions, are the main sources of development. They are not limited to writing a constitution or analyzing forms of government. They must also consider the ability of the government to govern and regulate society. The political institutions set up the stages in which economic institutions can be built [5] and their stability accelerates growth [13].

In economic literature, when analyzing the effect of political institutions on

${ }^{7}$ Example: democracy.

${ }^{8}$ Example: propriety rights. 
economic performance and economic growth, it generally refers to the shape of the political system (democracy or autocracy), political instability/stability or to governance.

Because of its ability to raise civil liberties, secure property and contract rights, the democratic process becomes a source of economic prosperity [14]. Indeed, political instability degrades economic growth by destroying physical and human assets, but also by diverting public spending from productive activities [15], it is a source of corruption [16] and thus, good governance appears as a catalyst for growth [17]. Using a dynamic panel model (GMM), some authors show that the democratic system is more likely to stimulate foreign investment, unlike other control variables such as inflation, market size, and economic growth [18].

Several studies have attempted to classify institutions and evaluate their impact on economic performance, and the resulting conclusions are varied. In fact, Flachaire et al. [7] proceeded to identify the type of institution that best promotes the growth regime. Using panel data, they show that economic institutions act positively on economic performance when political institutions are not significant. In the same vein, with a GMM system out of a sample of 109 countries, it has been shown that political institutions are of paramount importance only to emerging democracies.

Political stability and the regulation of economic activity have a positive influence on economic growth in Africa while the control of corruption, respect for the principles of the rule of law do not generate the expected effects mainly in countries deprived of natural resources [19]. By analyzing the situation of 15 African Saharan countries, Rodrik [20] has shown that these economies suffer from the lack of institutions of markets stabilization and legitimization, and this slows down growth. This conclusion is reinforced by the works which stipulate that only of the institutions of market stabilization, regulation and creation have a positive impact on growth in contrast to the legislation institutions [21].

Overall, it is clear from empirical works that if the countries' development level is correlated with economic institutions, political institutions for their part are not significant [22].

\subsection{Institutional Interaction on Economic Performance}

In developing countries, few studies have assessed the combination or interaction of two types of institutions on economic performance. Yet, in accordance with the work of Wagner [23] and Kurrild-klit Gaard and Berggren [24], it is obvious that one institutional category ${ }^{9}$ remains insufficient to create an institutional structure that can stimulate economic growth. However, it is advisable to mention that the effect of interaction between two institutional variables depends on the political experience of a country [25]. Therefore, when analyzing the impact of institutional interaction on economic performance, several scenarios in accordance with the works of authors who have analyzed the interaction 
between property rights and political power.

From a general analysis, we see first two extreme scenarios: as a consequence, we assume that we are in an environment where we have good economic and political institutions then such institutions are able to impulse economic performance. On the other hand, the combination of both weak political and economic institutions as is a real obstacle to economic performance. It should be noted that alongside these two extreme scenarios, there are also two intermediary scenarios: in one we better economic institutions, but weak political institutions and in the other, we have the reverse. However, only one institutional category remains insufficient to create an institutional structure capable of stimulating economic performance as previously stated. It is therefore these different hypotheses that we will test as part of our methodology, especially in Model 3 in Central Africa.

Nevertheless, economic theory globally suggests that institutions can interact in the following way: political institutions affect economic institutions mainly property rights through the decision-making power they provide, which in turn influences political institutions through their distributive consequences. The empirical challenge consists in estimating the dynamic development of the institutions in accordance with the endogeneity behind their mutual influence (Braunfels, 2014).

\section{The Methodological Framework}

The purpose of this section is to present the methodological framework of the study. We first present the construction of the composite indicator of political institutions using the Main Component Analysis technique needed to estimate our econometric model. Next, we evaluate the influence of institutions on the economic performance of Central African countries using the Generalized Moment Method.

\subsection{Construction of a Politico-Institutional Index (IPI)}

The construction of a composite indicator is explained by the fact that political institutions are, on the one hand, complex to measure in relation to economic institutions that is limited to economic freedom, and on the other hand, an individual indicator is insufficient to assess their impact on economic performance [26]. Therefore, our IPI is designed from several individual indicators of political institutions:

$$
\begin{aligned}
\text { ICinst }_{n}= & w_{1} \text { libcivil }_{1 n}+w_{2} \text { concorrup }_{2 n}+w_{3} \text { stabpoliti }_{3 n}+w_{4} \text { politicalrigh }_{4 n} \\
& +w_{5} \text { goveff }_{5 n}+w_{6} \text { duraregim }_{6 n}+w_{7} \text { regloi }_{7 n}
\end{aligned}
$$

ICinst $_{n}$ : composite indicator of political institutions in country $\mathrm{n} ; W_{\dot{r}}$ : weight attached to attribute i; regloi: rule of law; libcivil: civil liberties; concorrup: corruption control; stabpolitik: political stability; politicalrigh: political rights; duraregime: sustainability of the regime; goveff. public efficiency.

Overall our first two axes account for $86.60 \%$ of the total inertia of the point 
cloud (Table 1). The first factorial plan alone summarizes the information with $57.60 \%$ of the dispersion according to the maximum inertia criteria. The politico-institutional variables therefore contribute greatly to the production of axis 1 .

\subsection{Assessment of the Effects of Institution on Economic Performance}

To assess the individual effect and the combined effect of economic and political institutions on economic performance, we start from a type of Cobb-Douglas production function:

$$
Y=A K^{\alpha} H^{\beta}
$$

by putting this equation in the form of logarithm and introducing the temporal dimension we get:

$$
\ln Y_{t}=a_{t}+\alpha \ln K_{t}+\beta \ln H_{t} \quad \text { With } a_{t}=\ln A_{t}
$$

With $Y_{t}, a_{t}, K_{t}, H_{t}$ respectively representing economic performance captured by economic growth, Solow residual or technological parameter, physical capital and human capital. However, in the economic literature, it is generally accepted that the Solow residue is an exogenous variable. It therefore includes all the variables that can also lead to growth in national income. Already in his work, Mankiw (2002) demonstrates that capital and work alone are not enough to explain the totality of growth. Starting from this observation, we introduce at the level of the term, $a_{t}$ the institutions and a set of variables that can explain growth. This in order to increase the explanatory power of the model and reduce the possibility of omitting variables. The specification of the variables is inspired by the work of Flachaire et al. [7] and Kane and Diop [27].

Thus, to test the explanatory power of a synthetic indicator, we must study its relationship with other variables. In this context, we favor a dynamic panel model using the generalized moments technique (GMM) in Arellano's system. and Bond [8]. This technique solves the problem of endogeneity bias that exists between institutions and economic performance on the one hand, and the reciprocal influence existing between economic and political institutions on the other. This method also solves the problem of simultaneity bias, reverse causality and omitted variables. It exploits the variation of time series data, takes into account the specific effects invisible to each country, and allows the inclusion of delayed dependent variables as exogenous variables present in this type of regression. Our equations to test is as follows:

Model (1): Individual effect

$$
\begin{aligned}
\ln Y_{i t}= & \beta_{0}+\beta_{1} \ln \left(y_{i t-1}\right)+\beta_{2} \ln \left(G F C F_{i t}\right)+\beta_{3}\left(\text { insecoq }_{i t}\right) \\
& +\beta_{4} \ln \left(\text { pop }_{i t}\right)+\beta_{5}\left(\text { inspolitik }_{i t}\right)+\varepsilon_{i t}
\end{aligned}
$$

Model (2): Joint effect or combined effect

$$
\begin{aligned}
\ln Y_{i t}= & \beta_{0}+\beta_{1} \ln \left(y_{i t-1}\right)+\beta_{2} \ln \left(G F C F_{i t}\right)+\beta_{3}\left(\text { insecoq }_{i t}\right)+\beta_{4} \ln \left(\text { pop }_{i t}\right) \\
& +\beta_{5}\left(\text { inspoliti }_{i t}\right)+\beta_{6} \ln \left(\text { educ }_{i t}\right)+\beta_{7}\left(\text { instpolitik }_{i t} * \text { insteco }_{i t}\right)+\varepsilon_{i t}
\end{aligned}
$$


Table 1. Principal axes in analysis in principal component.

\begin{tabular}{cccccc}
\hline Axis & Eigen value & Difference & Proportion (\%) & Histogram & Cumulative (\%) \\
\hline $\mathbf{1}$ & 4.031977 & 2.001751 & $57.60 \%$ & $57.60 \%$ \\
$\mathbf{2}$ & 2.030226 & 1.570417 & $29.00 \%$ & $86.60 \%$ \\
$\mathbf{3}$ & 0.459809 & 0.201152 & $6.57 \%$ & $93.17 \%$ \\
$\mathbf{4}$ & 0.258657 & 0.089028 & $3.70 \%$ & $96.87 \%$ \\
$\mathbf{5}$ & 0.169629 & 0.130063 & $2.42 \%$ & $99.29 \%$ \\
$\mathbf{6}$ & 0.039566 & 0.029431 & $0.57 \%$ & $99.86 \%$ \\
$\mathbf{7}$ & 0.010135 & - & $0.14 \%$ & $100.00 \%$ \\
Tot. & 7.000000 & - & - & - & - \\
\hline
\end{tabular}

Source: author's estimate.

The variables are: Gross domestic product; Gross fixed capital formation (GFCF); economic institutions (insecoq); education (educ); population (pop); the political institutions (inspolitik); the economic institutions are measured by economic freedom ${ }^{10}$ which is also an aggregated indicator.

It should be emphasized that in model (2), the term interaction $\left(\right.$ instpolitik $_{i t} *$ insteco $\left._{i t}\right)$ is introduced to capture the combined effect of political and economic institutions on economic performance in the sense that we are in an environment where the variables interact, consequently such an effect is more important than the independent effect of each type of institution [25].

It should be mentioned that our econometric analysis covers ten (10) countries in Central Africa ${ }^{11}$ over the period 1996-2013 and uses secondary data from several sources.

\section{1) The dependent variable}

Economic performance is measured by the economic growth indicator is gross domestic product $\left(Y_{i t}\right)$. This is an economic indicator that makes it possible to measure the wealth produced within a country or a geographical area during a determined period [28].

\section{2) The independent variables}

Economic institutions are represented by the synthetic index of economic freedom (insecoq ) which consists of 10 variables according to Fondation Héritage [29], namely, free trade: tariff barriers to trade or not; tax freedom: the weight of taxes; the size of the government: the weight of public spending; mon-

\footnotetext{
${ }^{10}$ it is a synthetic index made up of 10 variables, namely, free trade: tariff or non-tariff barriers to trade; tax freedom: the weight of taxes; the size of government: the weight of public spending; monetary freedom: control of prices and the level of inflation; freedom of Investment: degree of restrictions on international capital flows; financial freedom: restrictions on financial services, difficulties to operate in the banking sector; freedom of corruption; property rights: influence of the government on justice, non-respect of the right of ownership; business freedom: number, speed and cost of procedures; freedom of work: various aspects of the legal and regulatory framework of a country's labor market.

${ }^{11}$ According to the configuration of ECCAS (Angola, Burundi, Cameroon, Congo, DRC, Gabon, Sao Tome \& Principe, Chad, Central African Republic, Equatorial Guinea).
} 
etary freedom: price controls and the level of inflation; the freedom to invest: degree of restrictions on international capital flows; financial freedom: restrictions on financial services, the difficulties of operating in banking; freedom of corruption; property rights: government influence on justice, violation of property rights; business freedom: number, speed and cost of the procedures; freedom of work: various aspects of the legal and regulatory framework of a country's labor market.

These institutions measure the ability with which property rights are protected and how individuals engage in a process of voluntary transactions [30]. Each variable takes a rating on a scale of 0 to 100 points. A high score is synonymous with good quality. From the scores assigned to these ten variables, we calculate a score which is the overall economic freedom.

The index of political instit ution (inspolitik) is in turn made up of indices and Gastil Kaufman [31], which the sustainability of the system is grafted in order to converge the definition of institution's policies Acemoglu [9]. Specifically, there are:

Civil liberties (libcivil) refers to freedom of expression, belief, association, organization, personal autonomy without interference from the State. Control of Corruption (concorr) measures the degree of confusion between the public interest and the private interest for officials and elites.

Political stability or absence of violence (stabpolitik): this indicator measures the perception of the probability of destabilization or overthrow of government by unconstitutional or violent means.

Political rights (politicalrigh) are rights that allow individuals to participate freely in the political process including the right to vote.

Government or Public Effectiveness (goveff): it analyzes responses regarding the quality of public service and provides information on the independence of the public service from internal and external pressures. It is a variable that also appreciates the level of commitment and credibility of political authorities to the demands of citizens.

The rules of law (regloi): Set of indicators that measure citizens' trust in social rules and compliance with these rules. It is the public perception of the level of delinquency, efficiency and predictability of the judicial system and the possibility of enforcing the Contracts.

The sustainability of the regime (duraregime): it represents the number of years that has gone by since the last change of regime or the end of the transition period defined by the lack of stable political institutions.

The other control variables consist of:

DelayedGDP $\left(Y_{i t-1}\right)$ indicates the dynamism of growth, but can also reflect the convergence term [32]. Under the convergence hypothesis, rich countries tend to grow more slowly than poor countries.

Population (POP) is introduced to monitor the potential effect of a variation in the size of the country. 
Gross fixed capital formation (GFCF) makes it possible to capture the rate of investment in an economy.

Education is captured by the high school enrollment rate, a proxy variable of human capital. Human capital influences growth by encouraging innovation and technologies that lead to productivity [32].

The control variables (GDP, population, education and GFCF) are from the World Development Indicators of the World Bank [33]. As for institutional variables, they come from several sources: economic freedom being a composite index, it captures economic institutions [29], sustainability of the scheme (PolityIV), variables such as that rule of law, public or government effectiveness, control of corruption, political stability or violence are from "World Governance Indicators" of the World Bank [33]. Civil liberties and political rights also called Gastil index come from Polity IV.

\section{Results and Interpretations}

This section is devoted to presenting the results. We present in turn the results of the descriptive statistics, the stationarity test on the variables, and finally we expose the results of our estimations.

Table 2 provides information on descriptive statistics, as well as measures of the variables used. Stationarity tests [34] [35] are performed on all variables. They make it possible to determine their order of integration.

The tests reveal that all the variables are stationary in level (Table 3). The fact that they have the same order of integration makes it possible to avoid biased estimates.

Table 4 gives the results of our estimates from the Method of Generalized Moments (GMM). According to it, Model 1 and Model 2 allowed us to show respectively the individual effect of political and economic institutions on performance. As for Model 3, it discusses the interaction effect of these institutions on economic performance in Central Africa.

Table 2. descriptive statistics of model variables.

\begin{tabular}{|c|c|c|c|c|c|}
\hline Variable & Measure & Average & $\begin{array}{l}\text { Standard } \\
\text { deviation }\end{array}$ & Low & Max \\
\hline GDP $(y)$ & Gross domestic product & $9.26 \mathrm{e}^{+09}$ & $1.06 \mathrm{e}^{+10}$ & $1.03 \mathrm{e}^{+08}$ & $5.73 \mathrm{e}^{+10}$ \\
\hline Educ & Secondary rate registration & 29.371 & 15.525 & 8.466 & 80.353 \\
\hline POP & Total population & $1.16 \mathrm{e}^{+07}$ & $1.56 \mathrm{e}^{+07}$ & 132000 & $6.75 \mathrm{e}^{+07}$ \\
\hline Inspolitik & $\begin{array}{l}\text { Composite index of } \\
\text { political institutions }\end{array}$ & 0.004 & 2.089 & -4.123 & 6.234 \\
\hline Insecoq & $\begin{array}{l}\text { composite index of economic } \\
\text { institutions gives by economic } \\
\text { freedom }\end{array}$ & 48.047 & 6.76 & 23.7 & 60.5 \\
\hline GFCF & Share of investment in GDP & 29.71 & 32.856 & 2.1 & 219.069 \\
\hline
\end{tabular}

Source: authors' calculations. 
Table 3. Stationarity test on the variables.

\begin{tabular}{|c|c|c|c|c|c|c|c|}
\hline Variables & Trend or cste & Stats-IPS & P-value & décision & Stat levin lin & Trend or cste & $\mathrm{P}$-value \\
\hline variables & Trend or cste & Stats-IPS & $\mathrm{P}$-value & decision & Stat levin lin & Trend or cste & $\mathrm{P}$-value \\
\hline POP & Trend and cst & -9.0922 & 0.0000 & stationary & -12.168 & Trend et cst & 0.0000 \\
\hline FBCF & Trend and cst & -7.02938 & 0.0000 & stationary & -6.144 & Trend et cst & 0.0002 \\
\hline Educ & Trend and cst & -1.87863 & 0.0301 & stationary & -7.944 & Trend et cst & 0.0000 \\
\hline Insecoq & Trend and cst & -2.59689 & 0.0047 & stationary & -12.657 & Trend et cst & 0.0000 \\
\hline$Y$ & Trend and cst & -5.51446 & 0.0000 & stationary & -11.159 & $\begin{array}{c}\text { without cst and } \\
\text { trend }\end{array}$ & 0.0000 \\
\hline Inspolitik & Trend and cst & -1.84110 & 0.0328 & stationary & -3.568 & $\begin{array}{c}\text { without cst and } \\
\text { trend }\end{array}$ & 0.0003 \\
\hline
\end{tabular}

Source: authors' calculations. cst: constant; trend: tendency.

Table 4. Overall result of the estimates.

\begin{tabular}{|c|c|c|c|}
\hline & Model 1 & Model 2 & Model 3 \\
\hline $1 \mathrm{PIB}_{\mathrm{t}-1}$ & $\begin{array}{c}0.9493869^{* * *} \\
(0.504335)\end{array}$ & $\begin{array}{c}0.703970 * * * \\
(0.21775)\end{array}$ & $\begin{array}{c}1.000000^{* * *} \\
(0.051233)\end{array}$ \\
\hline $\mathrm{L}$ population & $\begin{array}{c}0.0260178 \\
(0.0514706)\end{array}$ & $\begin{array}{c}-0.05063533^{\star *} \\
(0.0163228)\end{array}$ & $\begin{array}{c}0.0192755 \\
(0.0562044)\end{array}$ \\
\hline IFBCF & $\begin{array}{c}0.0700467^{* * *} \\
(0.263339)\end{array}$ & $\begin{array}{c}0.0635356 * * * \\
(0.0130364)\end{array}$ & $\begin{array}{c}0.1129946^{* * *} \\
(0.0370431)\end{array}$ \\
\hline Education & $\begin{array}{c}0.1772989^{* *} \\
(0.0834232)\end{array}$ & $\begin{array}{l}-0.026135 \\
0.0280282\end{array}$ & $\begin{array}{l}-0.0061688 \\
(0.0572172)\end{array}$ \\
\hline Inspolitik & $\begin{array}{c}-0.0916064 * * * \\
(0.0196024)\end{array}$ & & $\begin{array}{c}0.7778238 * * * \\
(0.2159473)\end{array}$ \\
\hline Insecoq & & $\begin{array}{c}-0.0170202 * * \\
(0.0069123)\end{array}$ & $\begin{array}{c}-0.0112992 * * * \\
(0.003451)\end{array}$ \\
\hline $\begin{array}{c}\text { Inspolitik }{ }^{*} \\
\text { insecoq }\end{array}$ & & & $\begin{array}{c}-0.0155594^{* * *} \\
(0.0042529)\end{array}$ \\
\hline
\end{tabular}

Source: authors' calculations. Significance: ${ }^{* *}=1 \%{ }^{* *}=5 \% ;^{*}=10 \%$; (.) the standard deviation.

In the first model as previously stated, we assess exclusively the effect of political institutions on economic growth. All things being equal, our results indicate that the political institutions in Central Africa exert a statistically significant effect, but negative on economic performance. Thus, a rise in the index score of political institutions of one point brings about a reduction of $0.09 \%$ of economic growth in Central Africa.

In our second model, we highlight the effect of economic institutions on growth. It should be remembered that these institutions are by definition the rules of the game that affect the regulation of economic activity. As for political institutions, our investigations reveal that economic institutions also appear to be an obstacle to growth. For the most part, an increase in the index score of economic institutions of one point brings about a decrease of $0.01 \%$ of economic 
growth in Central Africa.

Model 3 shows the joint or combined effect of political and economic institutions on economic growth. Our results show that this effect ${ }^{12}$ is significant with a negative coefficient. They thus reflect the conjecture that the coexistence of these two types of institutions (political and economic) is not sufficient to impulse economic growth in this sub-region of Africa. However, in the presence of the interactive term, the effect of political institutions is positive. This vision thus reinforces the analyzes of Justesen and Klitgaard [25] who have demonstrated that when we are in an environment in which one institutional category functions better than another, then globally such institutions remain insufficient to create an institutional structure capable of stimulating economic performance.

\section{- Interpretation of the results}

A priori, if it is accepted, as Pereira et al. [36], that the effect of political institutions varies according to the context of the study, it is weak when the region is developed and more important in the opposite case. The fact that political institutions in Central Africa have a negative impact on economic performance (model 1) is not surprising considering the elements characterizing political institutions in the economic literature namely: the form of government, instability or political turmoil and governance aspects.

A negative coefficient can therefore be explained in several ways: At first, when we look at the ranking of countries of Central Africa in governance, we find that the majority of countries in this region ranks below the threshold considered efficient. With regard to the Mo Ibrahim Foundation [37], in general, Central Africa appears to be the poorest region compared to other sub-regions of Africa in terms of governance. This position reflects the considerable effort to be deployed by these countries to improve their economic performance.

To this underperformance of governance is added the presence of frequent outbreaks of tension or conflicts in the area (Eastern DRC, Central African Republic ...). This subregion is also subject to growing insecurity following the rise of phenomena such as organized crime, cross-border crime ${ }^{13}$, and maritime piracy. These various scourges degrade the economy by, for example, diverting public spending from productive activities. Such an aspect confirms the idea of Aisen et al. [38] that political instability is an obstacle to economic growth.

In addition, the majority of Central African countries are characterized by a low level of democracy which results in a longevity of their regime and therefore a lack of transition system. This system reveals a model of quasi-family politico-institutional organization in which a minority of relatives occupies the first positions in the government apparatus and derives their main benefits from economic growth. Such a feature generally leads the economy to institutional sclerosis [39], since some individuals are organized to capture the rents, which is detrimental to economic performance. Our results are so consistent with those of Svenson [40] who shows that with distorting policies, political instability, so-

\footnotetext{
${ }^{12}$ Materialized by the interaction coefficient.

${ }^{13}$ Example: Boko haram.
} 
cial polarization, etc., political institutions cannot stimulate economic growth.

Our results also reveal that economic institutions are a drag on growth. Such a conclusion is in keeping with the work of Barro and Sala-i-Martin [32] who have already shown that there is a possibility that economic institutions negatively affect economic growth. Several explanations can follow from this observation:

Firstly, in the presence of economies like those of the countries of Africa Central, gangrene and disabled by the corruption, this creates uncertainty and insecurity, and where policies of control against this scourge are not sufficiently effective, economic institutions wouldn't be able to impulse economic performance.

It is also accepted in the economic literature that secure property rights contribute greatly to the prosperity of economies. Unfortunately, the countries in this sub-region are characterized by weak protection of rights ownership due to administrative procedures and complex costly, poor enforcement of contracts leading to high transaction costs and limited business activity [41]. The intervention of the state in the establishment of property rights is not effective. The standards and procedures in force in this region of Africa particularly in a country like Chad testify instead of an appropriation of economic by its leaders ${ }^{14}$.

Specifically in the area of business regulation, it is recognized that an environment in which governments, such as those in Central African countries, generally create barriers to the entry of new industries in order to protect their interests and promote the monopoly of a type of entity constitutes a restraint to the actions of economic institutions. This is explained by the fact that a monopoly situation leads to the implementation of practices of agreements by such companies and concentration of an economic sector. Instead of guaranteeing competition, the only source of innovation $\left(\mathrm{BM}^{15}[42]\right)$ such (anti-competitive) behaviors hinder the functioning of economic institutions and thus economic growth through the restriction of commercial freedom.

The financial sector, a significant component of the economic institutions of the countries in this sub-region, remains inadequate as to its level development to support these institutions and therefore economic performance. It is characterized by a low rate of banking, a low security of banking services, in short an absence of financial culture among the populations, etc., which justifies the poor scores recorded by these countries in terms of financial freedom.

The characters mentioned above thus confirm the ranking of the Foundation Héritage in which none of the countries of Central Africa is in the upper bracket ${ }^{16}$ economic freedom materializing their economic institutions. There is an absence of entrepreneurial freedom and that is why these countries are considered either as "rather unfree countries"17 either "non-free country"18 or re- 
pressed, which is a real handicap for economic performance.

However, in a context of globalization, economic institutions remain a prime factor of attractiveness and incentive, for example investments that are based not only on institutional elements, but also on industrial and commercial elements [43] necessary for economic performance.

In this sense, Gwartney et al. [30] argue that in high-level economic institutions countries, the GDP growth rate is $2.4 \%$, compared to the low level economic institutions countries which have in average a GDP growth rate per capita of $1.3 \%$ between 1980 and 1994 .

In sum, whatever the type of effect (individual or combined), our investigations reveal that the institutions are still insufficient to stimulate economic performance in Central Africa. This result is then nearly similarto Luiz investigations' [44] approaches, which suggests that there is no opportunity for institutions to boost growth in Africa. Such an assertion can be globally explained by the lack of incentives to invest resources, an elite with an unlimited economic and political power used for extractive purposes. Institutions are also characterized by corruption, the development of farm activities, poor public service delivery, instability and conflict leading to insecurity and whose origin is in the presence of polarized societies, so many evils that undermine the institutions and in particular those of the countries of Central Africa [45]. However, according to Luiz [44] it is difficult to reverse this trend in that these institutional structures are held by the elite that ensures their perpetuity of their interests.

\section{Conclusions}

This article revisits the relationship between (political and economic) institutions and economic performance through an analysis of individual and combined effects.

To achieve this goal, we have first built a composite index of institutions from Principal Component Analysis to take into account the multi-dimensional nature of this concept. On the other hand, we examined the individual and joint influence of political and economic institutions on economic performance in Central African countries. To do this, we conducted a dynamic panel data analysis through the generalized moment method covering 10 Central African countries over the period 1996-2013. The estimation of this model has led to the conclusion that the economic and political institutions are still insufficient to promote the economic performance of the countries of Central Africa regardless of the type of analysis. However, such a conclusion cannot be a calamity. This result, which is in line with several empirical studies, provides several lessons.

If we want to eliminate this paralysis which deprives of points of economic performance, it is necessary to make institutional change. In other words, it amounts to changing the rules of the economic, but also game political. The decisions, mainly economic, must be built on an economic rationality, which requires greater economic freedom in order to converge towards a productive effi- 
ciency. This paper also suggests that the decision-makers of the countries of the Central Africa should improve policies against corruption, which is one of the major scourges. Therefore, the rule of law must be reinforced with an independent justice and inclusive institutions. The consideration of informal institutions which have become now active players in political and economic life, can considerably improve the results of this article, which supposes the organization of a system for collecting information and statistical data on informal institutions in Africa.

\section{Conflicts of Interest}

The authors declare no conflicts of interest regarding the publication of this paper.

\section{References}

[1] FMI (2016) l'Afrique Subsaharienne, un Changement de Cap s'impose. Perspectives Economiques Regionales.

[2] North, D. (1990) Institutions, Institutional Change, and Economic Performance. Cambridge University Press, New York. https://doi.org/10.1017/CBO9780511808678

[3] North, D. (1994) Institutions. Journal of Economic Perspectives, 5, 97-112. https://doi.org/10.1257/jep.5.1.97

[4] Acemoglu, D., Johnson, S. and Robinson, J. (2004) The Colonial Origins of Comparative Development: An Empirical Investigation. American Economic Review, 91, 1369-1401. https://doi.org/10.1257/aer.91.5.1369

[5] Edison, H. (2003) Qualité des institutions et résultats économiques: Un lien vraiment étroit? Finances et développement, 35-37.

[6] Toye, J. (1995) The New Institutional Economics and Its Implications for Development Theory. In: Harriss, J., Hunter, J. and Lewis, C.M., Eds., The New Institutional Economics and Third World Development, Routledge, London, 49-68. https://doi.org/10.4324/9780203444290.ch4

[7] Flachaire, E., Garcia-Penalosa, C. and Konte, M. (2014) Political versus Economic Institutions in the Growth Process. Journal of Comparative Economics, 42, 212-229. https://doi.org/10.1016/j.jce.2013.05.001

[8] Arellano, M. and Bond, S. (1998) Dynamic Panel Data Estimation Using DPD98 for GAUSS: A Guide for Users. Institute of Fiscal Studies, London.

[9] Acemoglu, D., Johnson, S. and Robinson, J. (2005) Reversal of Fortune: Geography and Institutions in the Making of the Modern World Income Distribution. The Quarterly Journal of Economics, 117, 1231-1294.

[10] Wiggins, S. and Davis, J. (2006) Economic Institutions. IPPG Programme Office, IDPM, School of Environment \& Development.

[11] Pande, R. and Udry, C. (2005) Institutions and Development: A View from Below. Yale University Economic Growth Center. Discussion Paper No. 928.

[12] Acemoglu, D., Johnson, S. and Robinson, J. (2012) Institutions as the Fundamental Cause of Long-Run Growth. In: Aghionet, P. and Durlauf, S., Eds., Handbook of Economic Growth, North-Holland, Amsterdam, 386-472.

[13] de V. Cavalcanti, T.V. and Novo, A. (2005) Institutions and Economic Develop- 
ment: How Strong Is the Relation? Empirical Economics, 30, 263-276. https://doi.org/10.1007/s00181-004-0217-5

[14] Commander, S. and Nikoloski, Z. (2010) Institutions and Economic Performance: What Can Be Explained? Working Paper No. 121.

[15] Abessolo, I. (2003) Instabilité politique et Performances Economiques: Une Évaluation du cas du Tchad. Département de Sciences Economiques, Université de Yaoundé II, Yaoundé.

[16] Lalime, T. (2010) Croissance économique et instabilité politique en Haïti (1970-2008). Département des Sciences Economiques, Université de Montréal, Montréal, 53.

[17] Carrilo, S. and Fruchart, V. (2007) Bonne Gouvernance comme Catalyseur de la Croissance. Atelier source de croissance.

[18] Madani, S. and Nobakht, M. (2014) Political Regimes and FDI Inflows: Empirical Evidence from Upper Middle Income Countries. Journal of Finance and Economics, 2, 75-82. https://doi.org/10.12691/jfe-2-3-4

[19] Ondoa, H. (2013) Gouvernance et Croissance économique. African Developpement Review, 25, 130-147.

[20] Rodrik, D. (1999) Democracies Pay Higher Wages. Quarterly Journal of Economics, 114, 707-738. https://doi.org/10.1162/003355399556115

[21] Avom, D. and Song, S. (2012) Institutions économiques, capital humain et croissance économique en Afrique au Sud du Sahara. Université de Yaoundé II, Yaoundé.

[22] Glaeser, E.L., La Porta, R., Lopez-de-Silanes, F. and Shleifer, A. (2004) Do Institutions Cause Growth? Journal of Economic Growth, 9, 271-303. https://doi.org/10.1023/B:JOEG.0000038933.16398.ed

[23] Wagner, R.E. (1993) Parchment, Guns and Constitutional Order. Edward Elgar, Cheltenham Gloss.

[24] Kurrild-Klitgaard, P. and Berggren, N. (2004) Economic Consequences of Constitutions: A Theory and Survey. Journal des Economistes et des Etudes Humaines, 14, 3-41. https://doi.org/10.2202/1145-6396.1114

[25] Justesen, M.K. and klitgaard, K.P. (2013) Institutional Interactions and Economic Growth: The Joint Effects of Property Rights, Veto Players and Democratic Capital. Public Choice, 157, 449-474. https://doi.org/10.1007/s11127-013-0143-1

[26] Rodrik, D. (2002) Institutions for High-Quality Growth: What They Are and How to Acquire Them. Harvard University Press, Cambridge, MA, 49.

[27] Kane, C. and Diop, A. (2012) Risque Sociopolitique et Investissements Directs Etrangers en Afrique de l'Ouest. La Revue économique d Afrique de POuest, 1, 91-117.

[28] Easterly, W. (2002) Inequality Does Cause Underdevelopment: New Evidence from Commodity Endowments, Middle Class Share, and other Determinants of Per Capita Income. Working Paper No. 1, Center for Global Development, Center for Global Development, Washington DC.

[29] Heritage Foundation (2015) 2015 Index of Economic Freedom, Promoting Economic Opportunity and Prosperity. Wall Street Journal.

[30] Gwartney, J. and Lawson, R. (2008) The Concept and Measurement of Economic Freedom. European Journal of Political Economy, 19, 405-430. https://doi.org/10.1016/S0176-2680(03)00007-7

[31] Kaufmann, D., Kraay, A. and Zoido-Lobaton, P. (1999) Aggregating Governance 
Indicators. World Bank, Washington DC.

[32] Barro, R.J. and Sala-i-Martin, X. (1995) Economic Growth. McGraw-Hill, New York.

[33] World Bank (2014) World Development Indicators, CD ROM. Washington DC.

[34] Levin, A. and Lin, C.F. (2002) Unit Root Tests in Panel Data: Asymptotic and Finite Sample Properties. Discussion Paper, No. 56, University of California, San Diego.

[35] Im, K.S., Pesaran, M.H. and Shin, Y. (2008) Testing for Unit Roots in Heterogeneous Panels. Mimeo, Department of Applied Economics, University of Cambridge, Cambridge.

[36] Pereira, C. and Teles, V. (2010) Political Institutions and Substitute for Democracy: A Political Economy Analysis of Economic Growth. Manuscript presented at the Annual Conference of the European Economic Association.

[37] Mo Ibrahim Foundation (2014) Index of African Governance: Country Profiles. Ibrahim Foundation.

[38] Aisen, A. and Veiga, F. (2013) How Does Political Instability Affect Economic Growth. European Journal of Political Economy, 29, 151-167.

[39] Olson, M. (1982) The Rise and Decline of Nations. Yale University Press, New Haven, $\mathrm{CT}$.

[40] Svenson, J. (1998) Investment, Property Rights and Political Instability: Theory and Evidence. European Economic Review, 42, 1317-1341. https://doi.org/10.1016/S0014-2921(97)00081-0

[41] Morchid, S. (2010) La qualité des institutions constitue-t-elle une barrière à la relance économique? Application à un échantillon de pays africains. Codesria.

[42] World Bank (2005) Doing Business in 2005. The World Bank, Washington DC.

[43] Avom, D. and Carmignani, F. (2009) Is Mother Nature a Curse for Social Development. Macroeconomic Research Group Discussion Paper 27.

[44] Luiz, J. (2009) Institutions and Economic Performance: Implications for African Development. Journal of International Development, 21, 58-75. https://doi.org/10.1002/jid.1472

[45] World Bank (2002) World Development Report: Building Institutions for Markets. Oxford University Press, Oxford. 